\title{
Carnitine and Development of Newborn Adipose Tissue
}

\author{
E. SCHMIDT-SOMMERFELD, M. NOVAK ${ }^{(42)}$ D. PENN, P. B. WIESER, M. BUCH, AND P. HAHN \\ Department of Pediatrics, University of Miami School of Medicine, Miami, Florida, USA
}

\begin{abstract}
Summary
In newborn adipocytes, the oxidation and esterification of $\left[{ }^{14} \mathrm{C}\right]$ palmitate was increased after addition of $\mathbf{L}$-carnitine and decreased after addition of deoxycarnitine, a carnitine acyltransferase inhibitor (Table 1). In adult cells, the oxidation of $\left[{ }^{14} \mathrm{C}\right]$ palmitate was higher and the esterification of $\left[{ }^{14} \mathrm{C}\right] p a l m i-$ tate was lower compared to newborn adipocytes. There was no change in either oxidation or esterification after incubation with L-carnitine or deoxycarnitine.

Comparing samples obtained during the first day of life with those from newborns older than $30 \mathrm{hr}$, there was an increase in acid-soluble and acid-insoluble carnitine content (Figs. 1 and 2). Acid-insoluble carnitine levels were higher in adults than in newborns. Carnitine palmitoyltransferase activity increased in white adipose tissue mitochondria of normal fullterm infants after $20 \mathrm{hr}$ of age (Fig. 3).

Longitudinal measurements at different ages showed a constant individual blood level of free carnitine after birth (Fig. 4).

In human breast milk, the total carnitine content increased during the first week postpartum (Table 2). After 1 month of lactation, the values declined to those of milk samples obtained during the first 3 days postpartum. Commercial milk formulas with a cow's milk base had a similar or higher carnitine content than human milk. However, formulas with a soybean base had no detectable carnitine.
\end{abstract}

\section{Speculation}

Carnitine is accumulated in human newborn adipose tissue shortly after birth and increases the utilization of fatty acids for energy requiring processes. It remains to be established whether reduced oral intake of carnitine will adversely affect energy production or whether carnitine administration will be of benefit, particularly in the low birthweight infant.

Both lipolysis $(22-24,30)$ and the utilization of fatty acids $(6$, 8 ) increase in adipose tissue after birth. In numerous mammalian species, fatty acid oxidation plays an important role in the thermogenic function of brown adipose tissue. In contrast to newborn rodents, human newborn infants have a greater abundance of white than brown adipose tissue (9). Although the main function of white fat is probably to provide substrates (free fatty acids, glycerol) for other tissues of the body, its capacity to oxidize fatty acids increases postnatally (25).

Carnitine plays an important role in the oxidation of fatty acids by facilitating their transport across the inner mitochondrial membrane via a carnitine acyltransferase system $(5,28)$. The carnitine content and the activity of carnitine acyltransferases, important enzymes in fatty acid oxidation, increase in rat brown adipose tissue, heart, and liver after birth $(10,11,35)$.

Carnitine enhances the effect of norepinephrine on oxygen consumption in rats and mice (12). Inhibition of carnitine acyltransferases in suckling rats exposed to low ambient temperatures decreases oxygen consumption (11). These findings sug- gest that carnitine, as well as the carnitine acyltransferase system, play an important role in mechanisms associated with fatty acid oxidation in neonatal brown adipose tissue.

In human newborns, the possibility of studying brown adipose tissue is very limited. However, human newborn subcutaneous white adipose tissue shares certain characteristics with brown adipose tissue of rodents. It contains two types of adipocytes, small polyvacuolar cells and larger univacuolar cells. In some respect, the small polyvacuolar cells morphologically and metabolically resemble brown adipose tissue (19). Mitochondria isolated from these cells exhibit carnitine-dependent fatty acid oxidation, whereas mitochondria from the larger univacuolar cells, like those from adipocytes of adult white adipose tissue, do not increase oxygen consumption after addition of carnitine $(19,20)$. Carnitine elevates lipolysis in newborn adipose tissue fragments or isolated fat cells, but has no effect on adult tissue unless a lipolytic agent is present (27). These observations indicate the importance of carnitine in human adipose tissue metabolism during postnatal development.

Experimental data obtained in newborn mammals suggest that the dietary intake of carnitine may influence the postnatal metabolism of brown adipose tissue. It was shown that DL$\left[{ }^{14} \mathrm{C}\right]$ carnitine injected into lactating rats rapidly appears in milk. After ingestion by the suckling rats, it is accumulated preferentially in brown adipose tissue and to a lesser degree in other tissues (11). We were able to confirm this observation by oral administration of DL- $\left[{ }^{14} \mathrm{C}\right]$ carnitine to lactating rabbits (unpublished data).

We decided to further investigate the role of carnitine in human newborn infants during postnatal development. Carnitine content, the activity of carnitine palmitoyltransferase, and the effect of L-carnitine on oxidation and esterification of fatty acids were measured in subcutaneous white adipose tissue. Blood levels of carnitine were also determined. The carnitine content of human milk and commercial milk formulas was measured to evaluate nutritional availability.

\section{MATERIALS AND METHODS}

Subcutaneous white adipose tissue samples (20-60 mg) were obtained from the gluteal region of normal fullterm infants at 1 hr to 7 days of age and from adult volunteers using a percutaneous needle biopsy technique $(21,25)$ for which written informed consent was obtained (36).

\section{INCORPORATION STUDIES WITH ISOLATED FAT CELLS}

Fat cells were isolated from human adipose tissue by the method of Rodbell (31). The oxidation of ${ }^{14} \mathrm{C}$-labeled palmitate to $\mathrm{CO}_{2}$ as well as palmitate incorporation into triglycerides was studied in the presence of $1 \mathrm{mM} \mathrm{L-carnitine} \mathrm{(supplied} \mathrm{by} \mathrm{Grand}$ Island Biologicals, Grand Island, NY) or $1 \mathrm{mM}$ deoxycarnitine (supplied by Calbiochem, La Jolla, CA). The palmitate was complexed to albumin by the method of Ho et al. (15) to insure palmitate to albumin molar ratios of less than 3 . The cells were incubated in Krebs-Ringer bicarbonate buffer ( $\mathrm{pH} 7.4$ ) contain- 
ing half the usual amount of calcium and $4 \%$ bovine serum albumin plus $1 \mu \mathrm{M}$ palmitate containing $0.5 \mu \mathrm{Ci}[U-$ ${ }^{14} \mathrm{C}$ ]palmitate (supplied by New England Nuclear, Boston, MA) in a final volume of $0.5 \mathrm{ml}$. Triglycerides were separated by ascending thin layer chromatography. An ethyl ether-ethylacetate- $n$-hexane, 20:1:80 (v/v) solvent system was used. Carbon dioxide was absorbed in phenethylamine in absolute methanol $(1: 1)$. The triglyceride content of the fat cells was based on glycerol content (16) of an aliquot of extracted cells after saponification. The test for matched pair data was used for statistical analysis (Wilcoxon nonparametric).

\section{ADIPOSE TISSUE CARNITINE CONTENT}

Tissue samples were obtained as described above and immediately frozen in liquid nitrogen. Two different enzymatic methods were used to determine carnitine content, as follows.

Method $A$. The carnitine content of perchloric acid extracts was determined by a modification of the method of Marquis and Fritz (18). The small sample size necessitated lyophilization of the extract to achieve sufficient carnitine concentrations. The dry powder was redissolved in $0.5 \mathrm{ml}$ distilled water and a $0.3-$ $\mathrm{ml}$ aliquot was used for the assay which measured the reaction of 5,5-dithio-2-nitrobenzoic acid (DTNB) (supplied by Sigma Chemical Co., St. Louis, MO, as were all other chemicals, except as noted) with the coenzyme A formed during incubation of the sample with acetyl-CoA and carnitine acetyltransferase (EC 2.3.1.7). A Cary 118 spectrophotometer was used for the measurements.

Method B. The frozen tissue was homogenized in $0.3 \mathrm{ml}$ distilled water and centrifuged at $1000 \times g$ for $30 \mathrm{~min}$. A $0.05-$ $\mathrm{ml}$ aliquot of the supernatant was taken for protein determinations (17). The remaining supernatant was mixed with $0.6 \mathrm{ml}$ $0.6 \mathrm{M}$ perchloric acid. After centrifugation at $1000 \times g$ for 30 min, the resulting supernatant was neutralized with $\mathrm{KOH}$ and assayed for acid-soluble carnitine by the method of Cederblad and Lindstedt (4). This method is based on the measurement of labeled acetylcarnitine formed during incubation of the sample with $\left[{ }^{14} \mathrm{C}\right]$ acetyl-CoA (supplied by New England Nuclear) and carnitine acetyltransferase. The precipitate resulting from perchloric acid extraction contained acid-insoluble carnitine. It was hydrolyzed as described by Pearson and Tubbs (29) and assayed in the same manner as the acid-soluble fraction (4).

\section{CARNITINE PALMITOYLTRANSFERASE (CPT, EC 2.3.1.23) ACTIVITY} IN ADIPOSE TISSUE MITOCHONDRIA

Tissue samples were immediately homogenized in $0.25 \mathrm{M}$ sucrose containing $0.05 \mathrm{M}$ EDTA and $0.1 \mathrm{M}$ Tris buffer, $\mathrm{pH}$ 7.5. The method of mitochondrial isolation was the same as previously described (19).

Two different methods were used to determine CPT activity: In method A, the activity of CPT was assayed colorimetrically as described earlier (20) by measuring the reaction of DTNB with CoA released from palmitoyl CoA. For method B the method of Bremer (3) was modified as follows. The sample $(0.05 \mathrm{ml})$ was incubated with $\mathrm{DL}-\left[{ }^{14} \mathrm{C}\right]$ carnitine $(1.5 \mu \mathrm{mol})$, palmitoyl-CoA $(0.15 \mu \mathrm{mol})$, and potassium phosphate $\mathrm{pH} 7.5$ $(20 \mu \mathrm{mol})$ in a final volume of $0.15 \mathrm{ml}$ for $10 \mathrm{~min}$ at $37^{\circ}$. The reaction was stopped by adding $0.05 \mathrm{ml}$ concentrated $\mathrm{HCl}$. The mixture was extracted with $1.8 \mathrm{ml}$ distilled water and $1 \mathrm{ml} \mathrm{1-}$ butanol and centrifuged for $5 \mathrm{~min}$ at $1000 \times \mathrm{g}$. The butanol layer was removed and washed with water saturated with butanol. After centrifugation, $0.5 \mathrm{ml}$ of the washed butanol phase was counted in Triton toluene with a Packard liquid scintillation spectrophotometer. The results were expressed as nanomoles of palmitoylcarnitine formed per $\mathrm{mg}$ protein per min.

\section{CARNITINE CONTENT OF BLOOD}

Blood samples were obtained from heelpricks or mixed cord blood specimens of normal fullterm infants (46). A $0.1-\mathrm{ml}$ aliquot of whole blood was assayed for carnitine as described for white adipose tissue extracts by method $\mathrm{A}$.

\section{CARNITINE CONTENT OF MILK}

Breast milk samples were obtained at different stages of lactation (1 day to 3 years postpartum) and, after sampling, were frozen immediately. A $0.05-\mathrm{ml}$ aliquot was hydrolyzed as previously described (29) and the total carnitine content was assayed by the method of Cederblad and Lindstedt (4). Samples of commercially available formulas, ready for use, were assayed in the same manner.

The above measurements were statistically analyzed by the Student $t$-test.

\section{RESULTS}

INCORPORATION OF $\left[{ }^{14} \mathrm{C}\right]$ PALMITATE INTO $\mathrm{CO}_{2}$ AND TRIGLYCERIDES BY HUMAN NEWBORN ADIPOCYTES

Table 1 shows that in newborn adipocytes, the oxidation of $\left[{ }^{14} \mathrm{C}\right]$ palmitate was significantly increased after addition of Lcarnitine $(P<0.05)$ and decreased after addition of deoxycarnitine $(P<0.05)$, a carnitine acyltransferase inhibitor. Esterification of $\left[{ }^{14} \mathrm{C}\right]$ palmitate was also significantly increased after incubation with $\mathrm{L}$-carnitine $(P<0.01)$. There was a decrease in esterification after incubation with deoxycarnitine. In adult cells, the oxidation of $\left[{ }^{14} \mathrm{C}\right]$ palmitate was higher and the esterification of $\left[{ }^{14} \mathrm{C}\right]$ palmitate was lower compared to newborn adipocytes. However, there was no change in either oxidation or esterification after incubation with L-carnitine or deoxycarnitine.

\section{CARNITINE CONTENT IN HUMAN WHITE ADIPOSE TISSUE}

No significant difference was observed between methods A and $\mathrm{B}$ for measuring carnitine content and the results were combined (Figs. 1 and 2). Comparing samples obtained during the first day of life with those from newborns older than $30 \mathrm{hr}$,

Table 1. Incorporation of $\left[{ }^{14} \mathrm{C} J\right.$ palmitate into $\mathrm{CO}_{2}$ and triglycerides ${ }^{1}$

\begin{tabular}{|c|c|c|}
\hline Additions & Newborns & Adults \\
\hline \multicolumn{3}{|c|}{$\begin{array}{l}\text { Palmitate to } \mathrm{CO}_{2}, \mathrm{cpm} / \mu \mathrm{mol} \\
\text { triglyceride }\end{array}$} \\
\hline None & $105 \pm 21(7)$ & $261 \pm 127(4)$ \\
\hline L-Carnitine & $212 \pm 28(6)^{2}$ & $217 \pm 36(4)$ \\
\hline Deoxycarnitine & $51 \pm 12(6)^{3,4}$ & \\
\hline \multicolumn{3}{|c|}{$\begin{array}{l}\text { Palmitate to triglycerides, cpm } \\
\quad \times 10^{4} / \mu \text { mol triglyceride }\end{array}$} \\
\hline None & $3.5 \pm 0.6(7)$ & $1.1 \pm 0.4(4)$ \\
\hline L-Carnitine & $5.7 \pm 1.0(6)^{4}$ & $0.9 \pm 0.3(4)$ \\
\hline Deoxycarnitine & $2.1 \pm 0.4(6)$ & \\
\hline
\end{tabular}

${ }^{1}$ Fat cells were isolated from samples of human newborn tissue. The cells were incubated for $1.5 \mathrm{hr}$ in the presence of $1 \mu \mathrm{M}$ palmitate containing $0.5 \mu \mathrm{Ci}\left[U^{-14} \mathrm{C}\right.$ ]palmitate. Carnitine $(1 \mathrm{mM})$ or deoxycarnitine $(1 \mathrm{mM})$ was added as indicated. The data are the mean $\pm \mathrm{SD}$ and the number of determinations is given in parentheses.

${ }^{2} P<0.05$ compared to no addition.

${ }^{3} P<0.02$ compared to carnitine.

${ }^{4} P<0.01$ compared to no addition.
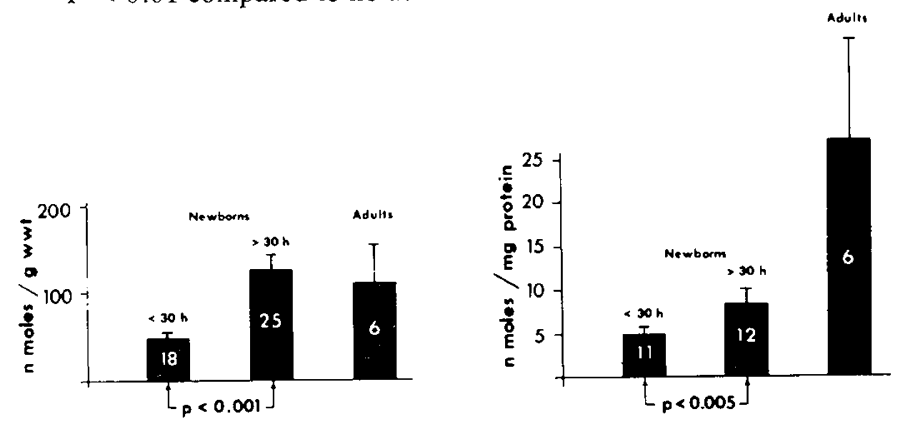

Fig. 1. Acid-soluble carnitine content of white adipose tissue of normal fullterm infants and adults. The data are the mean \pm SD for the number of cases indicated within the columns. 
there was a significant increase in acid-soluble carnitine content $(P<0.001)$. Although there were large individual variations in acid-soluble carnitine content of adult white adipose tissue, the mean value relative to tissue protein was higher than in newborn white adipose tissue. Acid-insoluble carnitine levels also increased significantly after $30 \mathrm{hr}$ of life $(P<0.05)$ and were higher in adults than in newborns $(P<0.01)$.

\section{CARNITINE PALMITOYLTRANSFERASE ACTIVITY IN HUMAN WHITE ADIPOSE TISSUE}

Both assay methods for carnitine palmitoyltransferase activity gave similar values. The combined results are given in Figure 3. There was a significant increase of carnitine palmitoyltransferase activity in white adipose tissue mitochondria of normal fullterm infants $20 \mathrm{hr}$ old $(P<0.001)$. In addition, the figure shows that in four premature infants (32-35 weeks of gestation), carnitine palmitoyltransferase activity was lower than in fullterm newborns of similar age. In adult white adipose tissue, the carnitine palmitoyltransferase activity was comparable to that of newborns less than $20 \mathrm{hr}$ old.
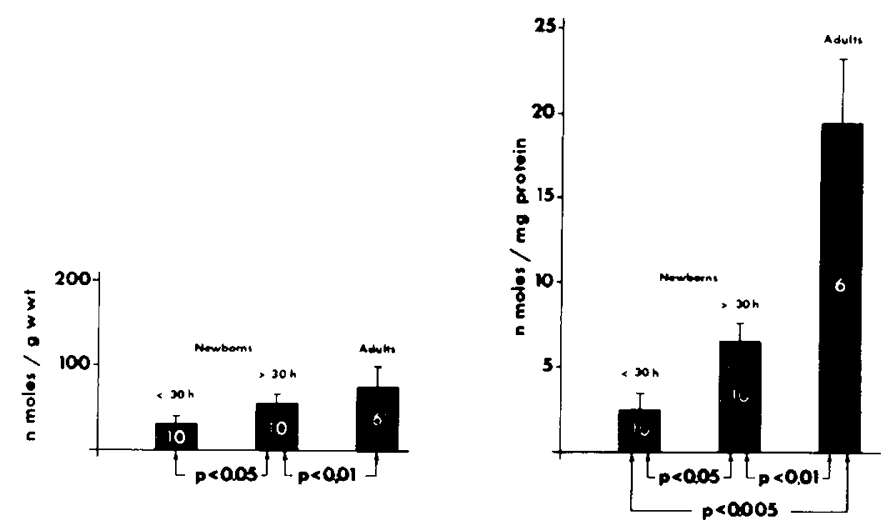

Fig. 2. Acid-insoluble carnitine content of white adipose tissue of normal fuliterm newborns and adults. The data are the mean \pm SD for the number of cases indicated within the columns.

\section{CARNITINE BLOOD LEVELS}

The values of free carnitine ranged from $10-60 \mathrm{nmol} / \mathrm{ml}$ of whole blood from newborns and adults (Fig. 4). There was no correlation between age and carnitine levels. Longitudinal measurements at different ages showed a constant individual blood level.

\section{CARNITINE CONTENT IN BREAST MILK AND COMMERCIAL FORMULAS}

The results are shown in Table 2 . In human breast milk, the total carnitine content increased during the first week postpartum $(P<0.005)$. After 1 month of lactation, the values declined to those of milk samples obtained during the first 3 days postpartum $(P<0.02)$ and did not significantly change even after 3 years of lactation in two cases.

Commercial milk formulas with a cow's milk base had a similar or higher carnitine content than human milk. However, formulas with a soybean base had no detectable carnitine.

\section{DISCUSSION}

Exogenous ${ }^{14} \mathrm{C}$-labeled fatty acids can be both oxidized (14) and esterified $(1,33,34)$ by adipose tissue in vitro. They can be used to label the pool of intracellular fatty acids permitting the measurement of changes in oxidation and esterification rate (14). The observation that carnitine increases the oxidation of $\left[{ }^{14} \mathrm{C}\right]$ palmitate in adipocytes isolated from human newborn adipose tissue (Table 1) again confirms the presence of a carnitine-dependent pathway for fatty acid oxidation as suggested by earlier results showing that carnitine increased oxygen consumption in isolated cells (20) and mitochondria (19) from newborn adipose tissue.

Newborn white adipose tissue has a higher rate of esterification of $\left[{ }^{14} \mathrm{C}\right]$ palmitate than that of adult white adipose tissue. This difference may be related to the elevated glycogen content in newborn white adipose tissue (26) providing a source of $\alpha$ glycerophosphate for triglyceride formation. The effect of carnitine on esterification in newborn white adipose tissue (Table 1) may be due to enhanced lipolysis (32), resulting in an increased supply of free fatty acids. The absence of a stimulatory effect of exogenous carnitine on fatty acid oxidation and esteri-

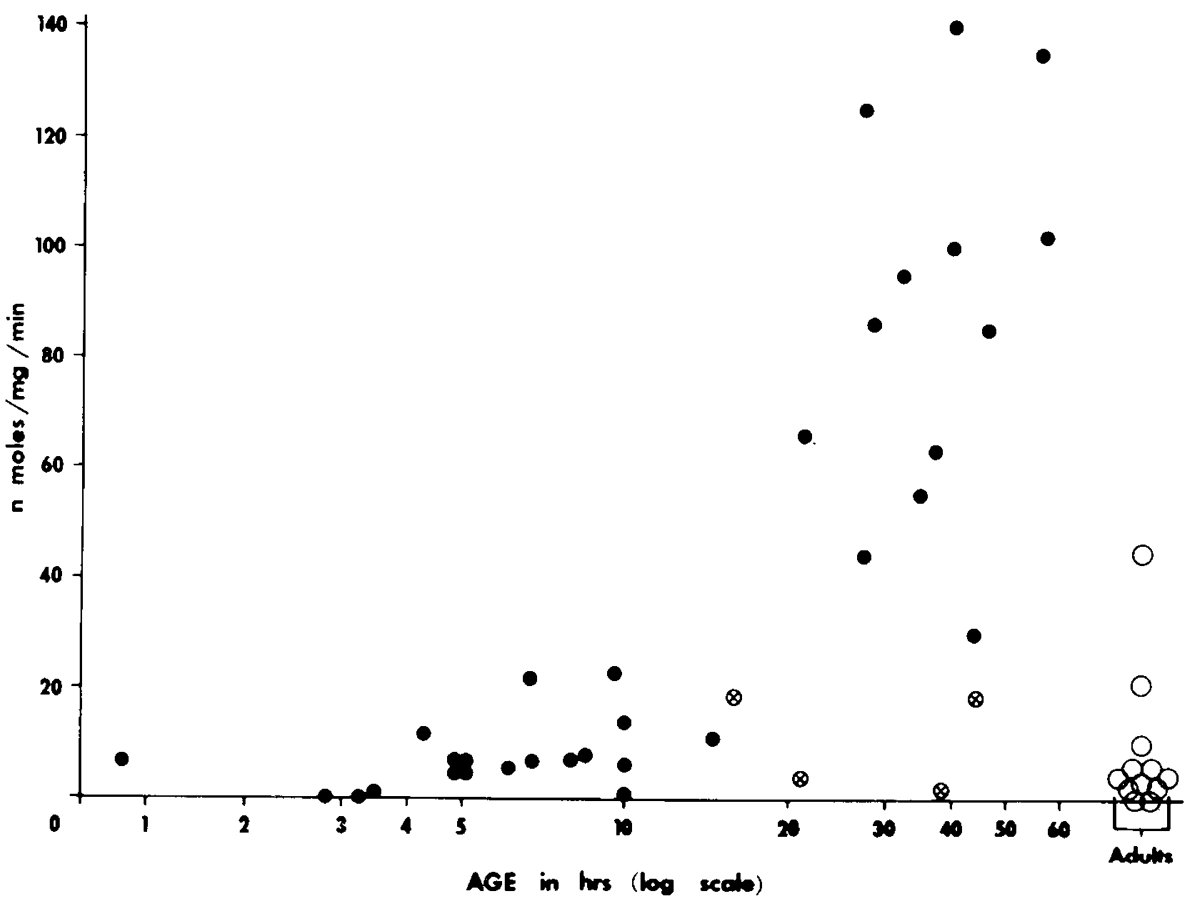

Fig. 3. Mitochondrial carnitine palmitoyltransferase activity in newborns and adults. Normal fullterm infants $(\bullet)$, premature newborns $(\otimes)$, and adults $(O)$. 


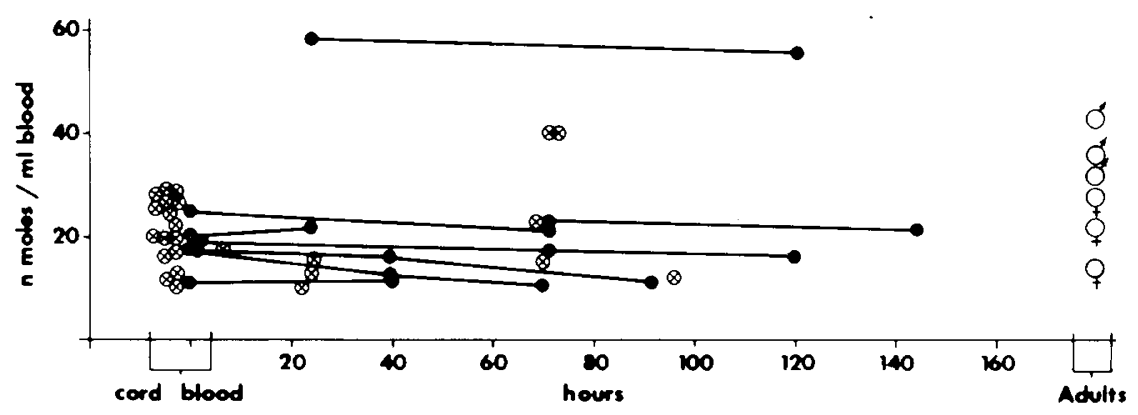

Fig. 4. Free carnitine content in whole blood of normal fullterm newborns and adults. The values represent single $(\otimes)$ and serial ( measurements of mixed cord blood or heelprick samples at the indicated ages.

Table 2. Total carnitine content in human milk and commercial formulas

\begin{tabular}{lc} 
& Concentration $(\mathrm{nmol} / \mathrm{ml})$ \\
\hline Human milk & \\
$1-3$ days postpartum & $39.0 \pm 2.4(n=5)$ \\
$4-7$ days postpartum & $63.4 \pm 9.5(n=10)^{1}$ \\
$\geq 1$ month postpartum & $45.2 \pm 5.3(n=20)^{2}$ \\
Cow's milk formulas & \\
Similac & $60-90(n=5)$ \\
SMA & $170-230(n=2)$ \\
Enfamil & $50-80(n=4)$ \\
Nutramigen & $75(n=1)$ \\
Soybean formulas & \\
Cho-Free & $0(n=2)$ \\
Pro-So-Be & $0(n=1)$ \\
Nur-Soy & $0(n=2)$ \\
Neo-Mull-Soy & $0(n=2)$ \\
Isomil & $0(n=1)$ \\
\hline
\end{tabular}

${ }^{1} P<0.005$ compared to $1-3$ days.

${ }^{2} P<0.02$ compared to $4-7$ days.

fication in adult adipose tissue is probably due to the high endogenous levels of carnitine in adult tissue (Figs. 1 and 2).

As previously reported, the carnitine palmitoyltransferase activity in mitochondria isolated from the adipose tissue of newborns older than 1 day of age is higher than in those from the white adipose tissue of adults (20). However, lower values observed shortly after birth, as well as in four premature newborns (Fig. 3), suggest that this enzyme undergoes early developmental changes in human white adipose tissue.

The increase in carnitine palmitoyltransferase activity after birth coincides with the increase in acid soluble (mainly free) and acid-insoluble (mainly long chain acyl) carnitine content (Figs. 1 and 2). The elevation in acid-insoluble carnitine may be associated with an increase in long chain fatty acid concentration in adipose tissue (2). At this time, it is not clear why there are higher levels of acid-insoluble carnitine in adult adipose tissue. Although there are objections to comparing human newborn white adipose tissue and neonatal rat brown adipose tissue, it is interesting that the carnitine content and carnitine palmitoyltransferase activities in these two tissues undergo similar changes (7).

The mechanism of carnitine accumulation in human newborn adipose tissue after birth is not fully understood, but the coincidence of this accumulation with the onset of feeding suggests that oral intake may play a role. This concept is supported by data obtained in experimental animals (10). However, little is known about de novo synthesis, absorption, turnover, and excretion of carnitine in the human newborn. Our finding that the blood levels of free carnitine remain relatively constant during postnatal development (Fig. 4) indicates a renal threshold for carnitine. In the urine of newborn infants, appreciable amounts of carnitine have been measured during the first hours of life before the onset of feeding (D. Penn, unpublished data) indicating placental transfer (13) or fetal synthesis of carnitine.

The detection of significant concentrations of carnitine in human breast milk (Table 2 ) raises the question whether nutritional supply of carnitine is important for the developing newborn. Although the cow's milk formulas studied contain levels comparable to or higher than those of human breast milk, there is no detectable carnitine in any soy milk formula investigated. A state of carnitine deficiency has not yet been described in the human newborn. Nonetheless, the importance of this substance in processes associated with fatty acid utilization suggests that its availability may be of clinical significance. This appears to be especially pertinent in infants whose oral intake is limited or whose condition does not allow feeding, e.g., premature infants dependent on long term parenteral alimentation.

\section{CONCLUSION}

1. Carnitine increased the oxidation and esterification of $\left[{ }^{14} \mathrm{C}\right]$ palmitate in human newborn adipocytes, but not in adult fat cells.

2. The acid-soluble and acid-insoluble carnitine content of newborn white adipose tissue increased after $30 \mathrm{hr}$ of age.

3. Carnitine palmitoyltransferase activity increased in fullterm newborn white adipose tissue after approximately 1 day of extrauterine life.

4. Individual carnitine blood levels remained relatively constant during early postnatal development.

5. The total carnitine content of human breast milk increased during the first week of lactation. Cow's milk formulas had a comparable or higher concentration than human milk, whereas the soybean base formulas examined had no detectable levels of carnitine.

\section{REFERENCES AND NOTES}

1. Angel, A., and Roncari, D. A. R.: The control of fatty acid esterification in a subcellular preparation of rat adipose tissue. Biochim. Biophys. Acta, 137: 464 (1967)

2. Boehmer, J.: Tissue levels of activated fatty acids (acylcarnitines) and the regulation of fatty acid metabolism. Biochim. Biophys. Acta, 144: 259 (1967).

3. Bremer, J.: Carnitine in intermediate metabolism: The biosynthesis of palmitylcarnitine by cell subfractions. J. Biol. Chem., 238: 274 (1963).

4. Cederblad, G., and Lindstedt, S.: A method for the determination of carnitine in the picomole range. Clin. Chim. Acta, 37: 235 (1972).

5. Fritz, I. B., and Marquis, N. R.: The role of acylcarnitine esters and carnitinepalmitoyltransferase in the transport of fatty acyl groups across mitochondrial membranes. Proc. Nat. Acad. Sci. U. S. A., 54: 1226 mitochondr

6. Hahn, P.: Lipid metabolism and nutrition in the prenatal and postnatal period. In: M. Winick: Nutrition and Development, pp. 99-134 (John Wiley and Sons, New York, 1972).

7. Hahn, P., and Kirby, L.: The effect of glucagon and diet on enzyme activities in brown fat and liver of the rat. Can. J. Biochem., 52: 739 (1974).

8. Hahn, P., and Koldovsky, O.: Utilization of Nutrients during Postnatal Development (Pergamon Press, Oxford, 1966)

9. Hahn, P., and Novak, M.: The development of brown and white adipose tissue. J. Lipid Res., 16: 79 (1975).

10. Hahn, P., and Skala, J.: Carnitine and brown adipose tissue metabolism in the rat during development. Biochem. J., 127: 107 (1972).

11. Hahn, $P$., and Skala, $J$. The role of carnitine in brown adipose tissue of 
suckling rats. Comp. Biochem. Physiol., 51 B: 507 (1975).

12. Hahn, P., Skala, J., and Davies, P.: Carnitine enhances the effect of norepinephrine on oxygen consumption in rats and mice. Can. J. Physiol. Pharmacol., 49: 853 (1971).

13. Hahn, P., Skala, J. P., Seccombe, D. W., Novak, M., Frohlich, J., PennWalker, D., Hynie, J., and Towell, M. E.: Carnitine content of blood and amniotic fluid. Pediat. Res., 11: 878 (1977).

14. Harper, R. D., and Saggerson, E. D.: Factors affecting fatty acid oxidation in fat cells isolated from rat white adipose tissue. J. Lipid Res., 17: 516 (1976).

15. Ho, R. J., Jeanrenaud, B., Pasternak, T., and Renold, A. E.: Insulin-like action of ouabain. II. Primary antilipolytic effect through inhibition of adenyl cyclase. Biochim. Biophys. Acta, 144: 74 (1967).

16. Kreutz, F. H.: Enzymatische Glyzerinbestimmung. Klin. Wschr., 40: 362 (1962).

17. Lowry, O. M., Rosebrough, N. J., Farr, A. L., and Randall, R. J.: Protein measurement with the Folin phenol reagent. J. Biol. Chem., 193: 265 (1957)

18. Marquis, N. R., and Fritz, J. B.: Enzymological determination of free carnitine concentration in rat tissues. J. Lipid Res., 5: 184 (1964).

19. Novak, M., Hahn, P., Pardo, V., Monkus, E., and Alzamora, D.: The effect of carnitine on respiration of mitochondria obtained from human newborn and adult subcutaneous white adipose tissue. Int. J. Biochem., 5: 223 (1974)

20. Novak, M., Hahn, P., Penn, D., Monkus, E., and Skala, J.: The role of carnitine in subcutaneous white adipose tissue from newborn infants. Biol. Neonate, 23: 11 (1973).

21. Novak, M., and Melichar, V.: Technique for sampling of human adipose tissue. Physiol. Bohemoslov., 10: 84 (1963)

22. Novak, M., Melichar, V., and Hahn, P.: Postnatal changes in blood serum content of glycerol and fatty acids in human infants. Biol. Neonate, 7: 179 (1964).

23. Novak, M., Melichar, V., and Hahn, P.: Changes in the content and release of glycerol in subcutaneous adipose tissue of newborn infants. Biol. Neonate, 8: 253 (1965).

24. Novak, M., and Monkus, E.: Metabolism of subcutaneous adipose tissue in the immediate postnatal period of human newborns. 1. Developmental changes in lipolysis and glycogen content. Pediat. Res., 6: 73 (1972).

25. Novak, M., Monkus, E., Wolf, H., and Stave, U.: The metabolism of subcutaneous adipose tissue in the immediate postnatal period of human newborns. 2. Developmental changes in the metabolism of ${ }^{14} \mathrm{C}-(\mathrm{U})-\mathrm{D}$ glucose and in enzyme activities of phosphofructokinase (PFK E.C.2.7.1.11) and $\beta$-hydroxyacyl-CoA dehydrogenase (HAD E.C.1.1.1.35). Pediat. Res., 6: 211 (1972).

26. Novak, M., Penn, D., and Monkus, $\overline{\mathrm{E}} .:$ Regulation of lipolysis in human neonatal adipose tissue: Effect of alteration in carbohydrate metabolism.
Biol. Neonate, 22: 451 (1973).

27. Novak, M., Penn-Walker, D., Hahn, P., and Monkus, E.: Effect of carnitine on lipolysis in subcutaneous adipose tissue of newborns. Biol. Neonate, 25 . 85 (1975).

28. Pande, S.: A mitochondrial carnitine acylcarnitine translocase system. Proc Nat. Acad. Sci. U. S. A., 72: 883 (1975).

29. Pearson, D. J., and Tubbs, P. K.: Tissue levels of acid insoluble carnitine in rat heart. Biochim. Biophys. Acta, 84: 772 (1964)

30. Persson, B., Copher, D., and Tunell, R.: Aspects on lipid metabolism in the immediate neonatal period in the newborn infant. In: G. Joppich and $\mathrm{H}$. Wolf: Stoffwechsel des Neugeborenen (Hippokrates, Stuttgart, 1970).

31. Rodbell, M.: Metabolism of isolated fat cells. I. Effect of hormones on glucose metabolism and lipolysis. J. Biol. Chem., 219: 375 (1964)

32. Rodbell, M.: Modulation of lipolysis in adipose tissue by fatty acid concentration in fat cell. Ann. N. Y. Acad. Sci., 131: 302 (1965).

33. Saggerson, E. D.: The regulation of glyceride synthesis in isolated white fat cells. The effect of palmitate and lipolytic agents. Biochem. J., 128: 1057 (1972).

34. Shapiro, B., Chowers, I., and Rose, G.: Fatty acid uptake and esterification in adipose tissue. Biochim. Biophys. Acta, 23: 115 (1957).

35. Warshaw, J. B., and Terry, M. L.: Cellular energy metabolism during feta development. II. Fatty acid oxidation by the developing heart. J. Cell Biol. 44: 354 (1970).

36. This research project was reviewed and approved by the Human Research Committee of the University of Miami School of Medicine. The procedure for obtaining the fat biopsy sample was explained in detail to the adult volunteers and to the parents of the newborns, and a written informed consent form was obtained for the adipose tissue and blood samples used for the studies.

37. The authors are indebted to Jeanne Cesteros for assistance in the preparation of this manuscript.

38. Dr. E. Schmidt-Sommerfeld was supported by Deutsche Forschungsgemeinschaft (Ausbildungsstipendium). Present address: University of Michigan Medical Center, Women's Hospital, Holden Nursery, Ann Arbor, MI 48106.

39. The present address of Dr. D. Penn is: Department of Pediatrics, William Beaumont Hospital, 3601 W. Thirteen Mile Road, Royal Oak, MI 48072.

40. The present address of Dr. P. Hahn is: Centre for Developmental Medicine, University of British Columbia, 811 West 10th Avenue, Vancouver, BC, Canada V $5 \mathrm{Z} 1 \mathrm{~L} 7$.

41. This research was supported by NIH Grant HD04946.

42. Requests for reprints should be addressed to: Dr. Milan Novak, Mailman Center for Child Development, P.O. Box 520006, Biscayne Annex, Miami, FL 33152.

43. Received for publication April 18, 1977

44. Accepted for publication August 3,1977 